\title{
A REALIDADE DOS PROFESSORES DE CIÊNCIAS NO ENSINO FUNDAMENTAL DE UM MUNICÍPIO DO MARANHAO
}

\section{THE REALITY OF SCIENCE TEACHERS IN ELE- MENTARY EDUCATION IN A MUNICIPALITY OF \\ MARANHAO}

\begin{abstract}
Anarleth Feitosa Aguiar ${ }^{1}$ João Francisco Rodrigues Peres ${ }^{2}$

Resumo: A Educação do Campo dos professores que atuam nas tem um vínculo com sujeitos soescolas do campo, e como objeticiais e com suas especificidades, vos específicos identificar o perfil exigindo do docente um trabalho dos docentes que atuam do $6^{\circ}$ ao diferenciado em relação a educa$9^{\circ}$ ano no ensino fundamental na ção urbana, mediando o diálogo escola do campo do município, entre teoria e prática pedagógica, investigar como são as práticas currículo e realidade do campo. pedagógicas dos professores nas Neste sentido, delineou-se como escolas do campo; compreender objetivo geral da pesquisa, anali- como estão sendo realizadas as sar como as formações continua- formações continuadas para os das contribuem para o desenvol- docentes que atuam em escolas vimento da prática pedagógica do Campo. Para tanto, foi reali-

1 Licenciada em Educação no Campo, da Universidade Federal do Piauí (UFPI)

2 Professor da Universidade Federal do Piaui

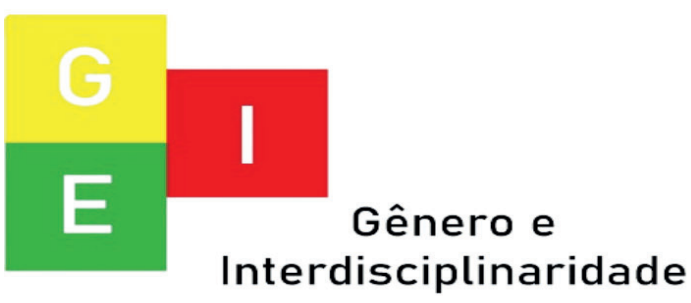


ISSN: 2675-7451

Vol. 02 - n 06 - ano 2021

Editora Acadêmica Periodicojs

zada uma pesquisa descritiva de caráter qualitativo, o instrumental utilizado foi entrevista com professores, e observações não participantes no contexto escolar. Os encaminhamentos da pesquisa mostraram que os professores possuem formação para atuarem do $6^{\circ}$ ao $9^{\circ}$ ano, porém, trabalham com diversas disciplinas, com o intuito de completar a carga horária proposta pela secretaria, além disso, as formações oferecidas, não contribuem de forma significativa, pois não são voltadas a realidade do campo e docentes sentem-se excluídos, pois tudo é voltado para a zona urbana.

Palavras-chaves: Educação do campo. Formação. Ensino de Ciências.

Abstract: The field education has a link with social subjects and their specificities, demanding from the teacher a differentiated work in relation to urban education, mediating the dialogue between theory and pedagogical practice, curriculum and reality of the field. In this sense, it was outlined as a general objective of the research, to analyze how the continuous training contributes to the development of the pedagogical practice of the teachers who work in the rural schools, and as specific objectives to identify the profile of the teachers who work from the 6th to the 9th year in the elementary school in the municipal school, to investigate how the teachers' pedagogical practices are in the rural schools; understand how ongoing training for teachers working in rural schools is being carried out. For that, a qualitative descriptive research was carried out, the instruments used were

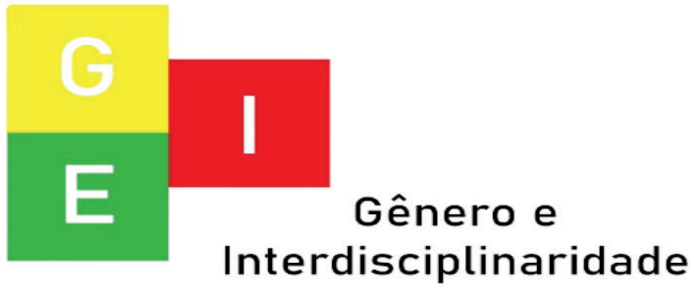


ISSN: 2675-7451

Vol. 02 - n 06 - ano 2021

Editora Acadêmica Periodicojs

interviews with teachers, and observations not participating in the school context. The research referrals showed that the teachers have training to work from the 6th to the 9th grade, but they work with several disciplines, aiming to complete the workload proposed by the secretariat, in addition, the courses offered do not contribute significantly, because they are not focused on the reality of the field and teachers feel excluded because everything is geared towards the urban area.

Keywords: Education of the field. Formation. Science teaching

\section{INTRODUÇÃO}

As relações entre ciências, tecnologia e sociedade no mundo contemporâneo são intensas, com impactos inevitáveis no ambiente educacional. Nesse contexto, é exigida formação do cidadão uma ênfase cada vez maior no entrelaçamento entre diferentes áreas do conhecimento, com reflexos nas práticas pedagógicas e nas formas de mobilizar os saberes docentes no ensino e aprendizagem de Ciências da Natureza nas escolas do campo, tendo em vista que em certos casos, ainda prevalece uma educação esquecida do ponto de vista político.

No âmbito da formação crítica, visa-se à qualificação das pessoas, o conhecimento deve fazer parte na ampliação dos horizontes, para a compreensão de um mundo que vive-se, em constantes mudanças, tendo em vista que a ciência cada vez mais, vem tornando-se. Diante disso, é importante a cada dia, a comunidade escolar, composta em parte por professores e alunos, necessi-

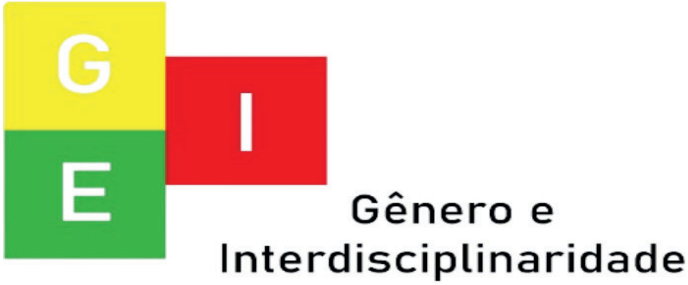


ISSN: 2675-7451

Vol. 02 - n 06 - ano 2021

Editora Acadêmica Periodicojs

tam estarem preparados para admitir tais fatos, que ocorrem no mundo globalizado.

Nessa perspectiva, o ensino de Ciências Naturais deriva "espaço privilegiado em que as diferentes explicações sobre o mundo, os fenômenos da natureza e as transformações produzidas pelo homem podem ser expostos e comparados" (BRASIL, PCN - Ciências, 1998, p. 25). Esse parâmetro correlacionado com as ideias dos PCN's de ciências, nos mostra que no campo pode se fazer comparações entre teoria e prática através de aulas de pesquisa de campo, certamente essa citação traduz que não é somente na cidade ou em escolas de alto padrão, que pode-se estar conciliando teoria e prática. No campo sem dúvida, o profissional que atua nessas escolas, pode está trazendo didáticas inovadoras que programe a educação, en- riquecendo os saberes dos alunos

da educação do campo.

Em se tratando do ensino de ciências, percebe se que há um acúmulo de conceitos que acaba sendo memorizado pelos alunos, não ocorrendo à colocação em prática desse conhecimento, que depois tornam se esquecidos pelos alunos. O professor tem que fazer um paralelo entre o que é repassado em sala de aula, com aquilo exposto no ambiente externo do ambiente escolar, buscar meio de realizar essa ligação entre teoria e prática, caso isso não ocorra à nomenclatura da ciência se torna meramente sem sentido. Contudo, é preciso que se busquem informações através de estudos como os professores das series iniciais e finais do ensino fundamental trabalham com conceitos científicos nas aulas de ciências.

Outro aspecto a ser ob-

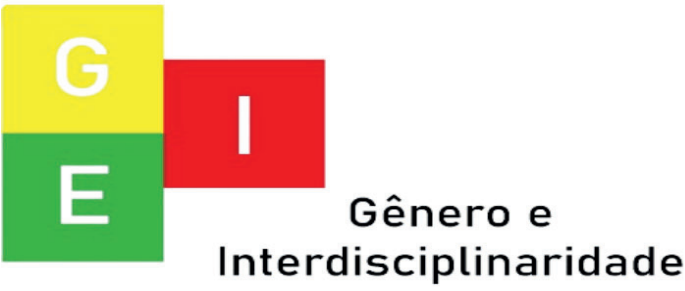


ISSN: 2675-7451

Vol. 02 - n 06 - ano 2021

Editora Acadêmica Periodicojs

servado, é a didática dos professores da área de Ciências Naturais. Cabe ressaltar que esse ponto também merece um estudo aprofundado, tendo em vista que esse campo é amplo e ao longo dos tempos têm vários estudos sendo realizado. Mesmo assim, muitas vezes, não dão continuidade e acabam ficando para trás, não chegando ao conhecimento dos docentes nas escolas do campo. Além disso, outro elemento que deve ser pesquisado é a formação do profissional na área específica de atuação, como ocorre e a como acontecem no campo, na área de Ciências Naturais.

No Decreto $n^{\circ} 7$. 352(4de novembro de 2010)Art. $1^{\circ} \S 4^{\circ} \mathrm{A}$ educação do campo concretizar-se-á mediante a oferta de formação inicial e continuada de profissionais da educação,garantia de condições de infraestrutura e transporte escolar,biblioteca áre- as de lazer e disposto adequados ao projeto política pedagógico e em conformidade com a realidade local e adversidade das populações do campo.

Segundo os estudos de Cleonice et al.( 2011), apontam que a formação dos docentes, principalmente na área especifica, apresentam suas precariedades, por outro lado, os cursos também de didática e metodologia demonstram uma séries de problemas.

Diante disso, cabe ressaltar que a formação na área especifica necessita de mais estudos e pesquisa, pois de acordo com o autor tem partes que ainda apresentam dificuldades, o que acaba gerando certas preocupações diante dos profissionais que atuam nas mais diversas disciplinas de Ciências Naturais.

Todavia, é imprescindível destacar de acordo com o

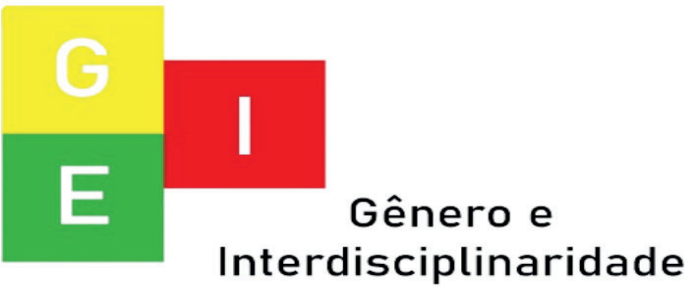


ISSN: 2675-7451

Vol. 02 - n 06 - ano 2021

Editora Acadêmica Periodicojs

tema proposto que a maioria dos

alunos não compreende as ciências, principalmente os que estudam, portanto para reverter essa situação baseiam se em tecnologias que utilizam no dia a dia (MILLAR，1996; STINNER \& WILLIAMS, 1998). Tal, indagação remete-se a provocação em pequenas coisas que poderão ser utilizados na explicação da ciência, tendo em vista que esse campo é vasto e extenso.

No âmbito da busca por respostas concretas em relação ao tema tratado, surgem então, as questões norteadoras que induzem aos questionamentos: Qual o perfil dos docentes que atuam do $6^{\circ}$ ao $9^{\circ}$ ano do Ensino Fundamental que atuam na Educação do Campo?Como são as práticas pedagógicas dos professores nas escolas do campo? Qual a importância na formação continuada para os docentes no desenvol- vimento de sua prática docente na Educação do Campo? Diante disso, delineou-se como questão problema da pesquisa: Como as formações continuadas contribuem para o desenvolvimento da prática pedagógica dos professores que atuam nas escolas do campo? Assim, definiu-se como objeto de estudo as formações continuadas de professores em escolas do campo.

Assim, delineou-se como objetivo geral da pesquisa, analisar como as formações continuadas contribuem para o desenvolvimento da prática pedagógica dos professores de ciências que atuam nas escolas do campo, e como objetivos específicos: identificar o perfil dos docentes que atuam do $6^{\circ}$ ao $9^{\circ}$ ano no ensino fundamental de ciências na escola do campo; investigar como são as práticas pedagógicas dos professores de

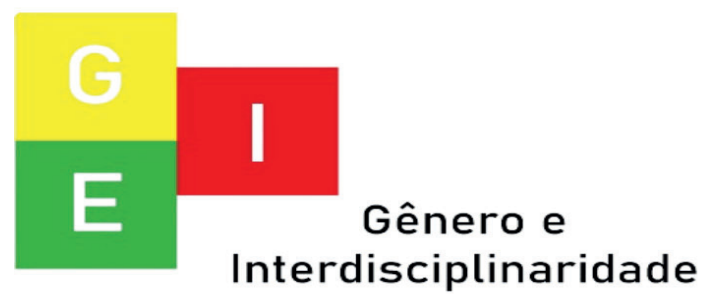


ISSN: 2675-7451

Vol. 02 - n 06 - ano 2021

Editora Acadêmica Periodicojs

ciências nas escolas do campo; xão sobre a formação no texto da compreender como estão sendo realizadas as formações continuadas para os docentes que atuam em escolas do Campo.

É muitos fácil abordar o quesito prática pedagógica, mas no fazer demanda certo questionamento e forma de abranger de maneira sucinta, por isso, ao tratar a questão, convém afirmar que as diretrizes de políticas públicas o consideram como algo reprodutor de fazeres e ações externas aos sujeitos, gerando uma abrangência que são: por que não conseguimos mudar a prática? De acordo com os estudos de Franco (2006), o mesmo toca nessa questão demonstrando que a prática pode mudar quando houver o envolvimento critico e reflexivo dos sujeitos da prática.

Neste sentido, o presente texto busca em um primeiro momento, fazer uma breve refleeducação. Em seguida, delinearam-se os passos da construção da pesquisa, no momento seguinte buscou-se realizar as análises das falas e observação da prática escolar e dos docentes, e por fim, esboçamos as considerações finais. A escolha do referido tema, tem por base um processo de experiência pessoal e profissional, pois é onde a pesquisadora exerce atividade como supervisora no campo. Diante das observações experiência das neste percurso, e foi visualizada a necessidade de formação, uma vez que foi percebida, a importância da construção constante de conhecimentos, os quais ajudam a entender melhor as situações inesperadas, que surgem no dia a dia na sala de aula.De acordo comas observações com relação a desenvolvimento nas realizações de projetos nas escolas,cujos da séries

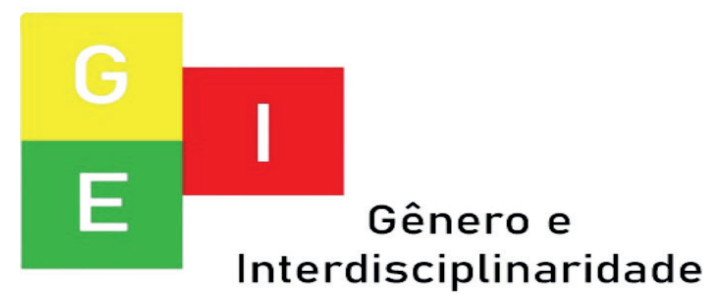


ISSN: 2675-7451

Vol. 02 - n 06 - ano 2021

Editora Acadêmica Periodicojs

iniciais da educação infantil a0 $5^{\circ}$ ano do ensino fundamental menos,tinham resultados significativos e os do ensino fundamental maios cujo são alunos do $6^{\circ}$ ao $9^{\circ}$ ano tinham,essa dificuldade de desenvolver projetos e sempre resistir em realizar os mesmos,e sempre eram os professores de ciências que demonstravam essa resistência.

\section{A FORMAÇÃO NO CON- TEXTO DA EDUCAÇÃO DO CAMPO}

A educação de acordo com a Constituição Federal/CF de 1988 é um direito de todos os cidadãos. Tal citação, está de acordo lei de Diretrizes e Bases da Educação Nacional-LDB 9.394/96. Sobretudo, ao discorrer a respeito dos direitos educacionais que se tem, é necessária que haja um paralelo no quesito a relevância que a educação nos mostra, independentemente de classe social, religião, orientação sexual fazem parte, todos têm direito a uma educação de qualidade e transformadora, que dialogue com todos abordando o contexto da inclusão embora ainda permeie a questão da exclusão social, mas todos devam está incluídos.

É dever do Estado, proporcionar a educação sendo de direito fundamental e, portanto, precondição para a preparação e para o exercício uma cidadania ativa e participativa. Não é por acaso, assim que a Constituição Federal de 1988 determina direito universal (direito de todos) a educação, sendo por isso, dever do Estado e da família, em seu Artigo 205(CF), o Estado cabe garantir o total acesso á prestação de serviços da espécie (serviços educacionais) a todos os

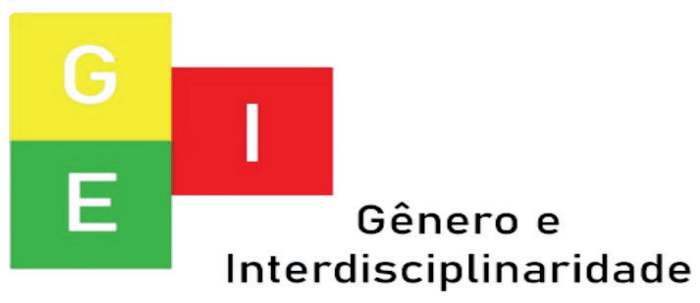


ISSN: 2675-7451

Vol. 02 - n 06 - ano 2021

Editora Acadêmica Periodicojs

cidadãos.

Conforme estabelece a

Lei de Diretrizes e Bases da Educação Nacional - Lei no 9.394, de 20 de dezembro de 1996 (LDBEN/ 96), que indica em seu artigo 03, (p. 07), no tocante dos Princípios e Fins da Educação Nacional: "I- a igualdade de condições para o acesso e permanência na escola".

Portanto, o ensino juntamente com a escola deve proporcionar acessibilidade de todas as formas aos alunos, ao fazer uma retrospectiva, ainda tem escola que não tem acesso para pessoas com alguma necessidade especial, tal problema se deve na elaboração do projeto das escolas, sendo assim reflete no ensino, principalmente das escolas do campo.

Percebe-se, que no campo legislativo, a educação houve evolução em prol dos indivídu- os para que os mesmos possam

evoluir, porém não especifica em nenhum momento a exclusão da educação do campo com os mesmos direitos.

A educação do campo visa formar cidadãos conscientes e livres, através de práticas que associam conteúdos e assuntos do cotidiano, assim ela se caracteriza como especifica e diferenciada, elaborada para atender necessidades dos alunos das famílias trabalhadoras do campo (PARANA, 2006).

A discussão a cerca da educação do campo deve ser priorizada nas escolas da zona rural, embora haja uma discussão sobre o tema entre professor e aluno, nota que esse diálogo merece ser mais forte, onde toda a comunidade escolar deve estar envolvida. Portanto, observa que muitos do Projeto Político Pedagógico, nem ao menos fala em educação

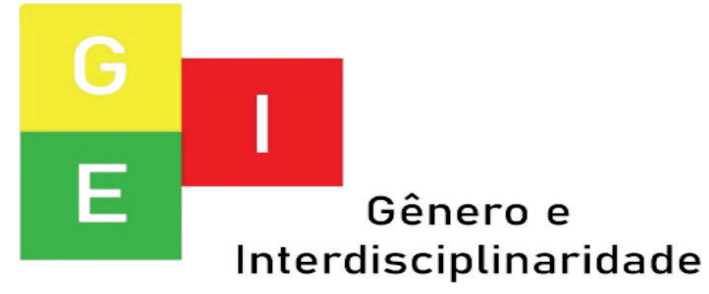


ISSN: 2675-7451

Vol. 02 - n 06 - ano 2021

Editora Acadêmica Periodicojs

do campo, certamente tal projeto deve ser inserido uma abordagem a respeito das lutas pela a educação do campo. De acordo com Moura e Santa (2012, p.3), fala que em se tratando dos PPPs das escolas situadas no contexto rural, nenhum deles discutiam as questões da Educação do campo, ou seja, predomina a "ideologia urbanocêntrica".

No entanto, de acordo com os PCN (Brasil, 1998, p.26) “(...) o ensino de Ciências Naturais tem sido frequentemente conduzido de maneira desinteressante e pouco compreensível”. Sendo assim, outro fato que merece observação discorre a respeito da ausência de atividades experimentais, por exemplo, aulas práticas, pois tem sido apontada como uma das principais deficiências (ARRUDA; LABURÚ, 2001).

Baseado nas informa- ções acerca do ensino de ciências, convém salientar que a necessidade de construir conceito sobre o ensino de Ciências $\mathrm{Na}-$ turais, parte de um pensamento que deve ser trabalhado desde as séries iniciais do ensino fundamental. Concretizando que há necessidade na formação desses profissionais, pois o que mais se houve falar são as deficiências no quesito a formação acadêmica dos profissionais nessas áreas. No tocante o ensino de ciências, desde as primeiras séries de escolaridade é amplamente preconizado no Brasil a partir da década de 1970, com a implantação da Lei 5.692, de 11 de agosto de 1971 (BRASIL, 1971), se sucedeu a obrigatoriedade do ensino de Ciências a todas as séries do Ensino Fundamental.

É notável, a necessidade do professor do ensino de ciências, busque novas metodologias

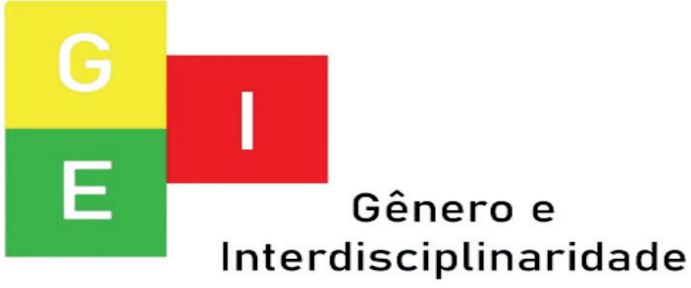


ISSN: 2675-7451

Vol. 02 - n 06 - ano 2021

Editora Acadêmica Periodicojs

para a prática de ensino, que motivem os discentes a aprenderem, a valorizar o conhecimento adquirido e que de fato seja uma aprendizagem significativa. Para Cachapuz (1989), o processo de investigação deriva da oportunidade de o professor fazer uma reflexão sobre a sua prática. $\mathrm{Na}$ abordagem ao pensar a respeito da prática pedagógica, o professor deve procurar metodologias condizente a realidade dos educandos, estimulando os mesmos para o campo da pesquisa, como também na interpretação e no entendimento de conceitos cientifico, aproximando para perto dos alunos, situações concretas explicadas pela ciência que está ao alcance deles. Com isso, o professor tem um papel fundamental para essas indagações descritas nesse contexto, trazendo para sala de aula debates sobre informações de artigo cientifico, textos postados em site seguro da internet, sendo que todos possam ser a respeito do tema tratado em sala de aula.

$$
\text { É importante conside- }
$$
rar a atuação dos professores das escolas do campo no ensino de ciências, como um fator fundamental para ajudar aos educandos na compreensão do mundo e suas transformações, além do reconhecimento do homem como parte do universo e como indivíduo.

Quando se fala da formação de professores, cabe salientar que demanda certo estudo dos conteúdos a serem ministrados, além de pesquisas sobre sua disciplina, tendo em vista que futuramente, constantemente os docentes são cobrados pela escola. No campo da pesquisa, alguns pesquisadores como Tardif (2005), compreendem que quando se trata da formação de pro-

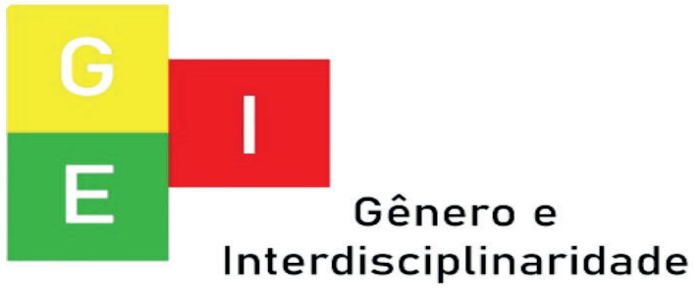


ISSN: 2675-7451

Vol. 02 - n 06 - ano 2021

Editora Acadêmica Periodicojs

fessores, está associada com as atividades práticas do cotidiano, sendo vinculada aos saberes docentes que possuem. Neste sentido, englobam conhecimentos, habilidades, responsabilidade que vem sendo construídos desde formação inicial e (re) construídos durante a formação continuada, como também, dos saberes advindo da sua experiência enquanto docente atuante em sala de aula.

De acordo com o autor, é importante lembrar que a prática docente faz diferença na sala de aula, o domínio do conteúdo no repassar as informações para os alunos tornando as aulas "show" e com um alto índice de aprendizagem significativo.

Os estudos realizados nas últimas três décadas, Schnetzler (2002), desse modo na literatura à formação de professores, em particular no âmbito das Ci- ências Naturais, demonstram que geralmente, os professores não têm tido formação adequada para dar conta do processo de ensino e aprendizagem de seus alunos, em qualquer nível de escolaridade.

Com relação à prática a pedagógica dos professores, é importante falar que essa temática vem no âmbito da identidade docente diante do profissionalismo, é um ingrediente que se constrói ao longo da prática, considerando a subjetividade, a força de vontade e a determinação em querer fazer mudanças, visando o ensino e aprendizagem dos alunos.

Para pesquisadora $\mathrm{Pi}-$ menta (2000, p.3): a prática está na raiz da re-significação epistemológica. Em geral pesquisam sobre e não a partir da educação, ou seja, não colocamos problemas da prática educativa no princípio de suas preocupações.

Essa proposta da práti-

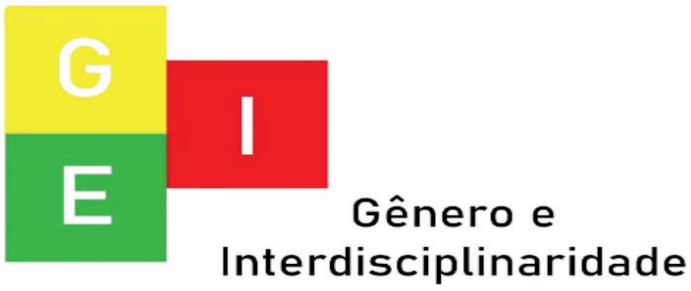


ISSN: 2675-7451

Vol. 02 - n 06 - ano 2021

Editora Acadêmica Periodicojs

ca, surge de um questionamento que nasce na graduação, pois as disciplinas pedagógicas devem fazer parte da graduação, ou seja, em muitos órgãos de ensino seja público ou privado, essas ideias de disciplinas citadas acabam ficando esquecida, ou seja, não dão a devida importância que elas trazem, onde futuramente na atuação como profissional fará falta em certas ocasiões. Portanto, a valorização e o respeito da carga horária não poderão ficar de fora, na graduação não devem ocorrer só aulas teóricas, mas projetos interdisciplinares farão diferença para os discentes que estão vivenciando essa formação acadêmica, construindo uma ideologia de professor pesquisador.

Outro elemento que deve ser executado pelos profissionais do ensino de ciências, são as atividades de campo, essas aulas práticas quando bem planejada surte efeito no ensino e aprendizagem dos alunos, para isso o professor precisa abrir mão da sua zona de conforto, pois em alguns essas realidades é visível nas escolas do campo. Além disso, existem muitos conteúdos ministrados em sala de aula, que pode ser trabalhados fora do ambiente escolar, conciliando teoria e prática.

Para Fernandes (2007, p. 22) define atividade de campo no ensino de Ciências como "toda aquela que envolve o deslocamento dos alunos para um ambiente alheio aos espaços de estudo contidos na escola”. Quando o aluno tem a oportunidade de ir ao campo com o objetivo de aprender, motivado pelo o professor nessa viagem ela interage com o ambiente, fazendo assimilação entre o que aprendem na sala com a realidade do campo na prática, onde podem surgir dúvi-

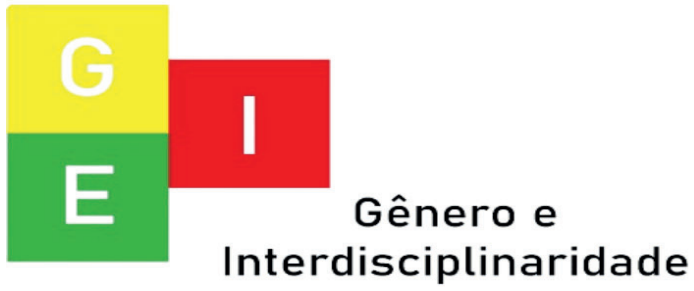


ISSN: 2675-7451

Vol. 02 - n 06 - ano 2021

Editora Acadêmica Periodicojs

das que talvez não possa ser compreendida no ambiente interno, mas fora poderão ficar a vontade e sanar todos os questionamentos que parece ser difícil o entendimento.

De acordo com Sobrinho (2009), para a compreensão dos conhecimentos, os alunos precisam estabelecer relações entre o que aprenderam e a realidade, aprender a partir de seus conhecimentos prévios nos questionamentos, experimentos e pesquisas associados à aula teórica. Portando, abordar os conteúdos de ciências procurando a compreensão dos processos e a reconstrução do conhecimento significativo do aluno é uma forma de exercer, com competência, o oficio de professor educador.

De acordo com Paulo Freire (1987 apud Gomes, 2009) as concretizações dos temas geradores ocorrem entre educador e educando na investigação da realidade, estudando e analisando criticamente as suas contradições e o movimento histórico da sua constituição. A educação pautada na realidade dos indivíduos, defendida por Paulo Freire, qual responsabiliza a educação pelo papel fundamental no processo de libertação dos homens.

Essa educação que Paulo Freire defende, caracteriza como sendo um processo revolucionado diante das situações postas em sociedade quebrando as barreiras da educação bancária, onde há um opressor em frente o oprimido. Deve- se formar cidadão com pensamento e visões críticas, formando opiniões próprias com um olhar transformador da realidade.

\section{CAMINHOS TRILHADOS}

NA PESQUISA

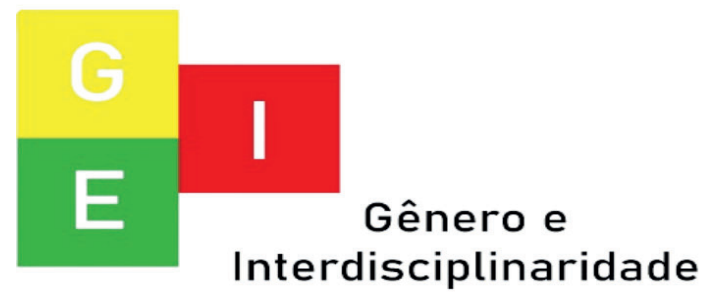


ISSN: 2675-7451

Vol. 02 - n 06 - ano 2021

Editora Acadêmica Periodicojs

Essa pesquisa foi desen- sadores qualitativos que estão

volvida nos povoados Perdido, preocupados com o processo e Onça,Senador Archer em escolas não simplesmente com os resuldo campo, do município de Ti- tados e o produto; os pesquisadomon Maranhão.

res qualitativos tende a analisar

Trata-se de uma pesquiseus dados indutivamente". Essa sa descritiva, de caráter qualitativo. Conforme Oliveira (1982), quando se trata da pesquisa qualitativa deve lembrar-se que é subjetiva, pois não opera com dados matemáticos, desse modo quando há a presença desses dados descobre as relações no tocante a tratamento estatístico. Nessa fala, o autor vem discorrer sobre a relevância que a pesquisa qualitativa traz, mesmo não tendo efeitos da parte da matemática, mas mesmo assim quando bem feito seus efeitos positivos nos resultados.

$\mathrm{Na}$ visão de Triviños (1987, p. 128-30), “a pesquisa qualitativa é descritiva; outro ponto importante são os pesquivisão do autor remete a pensar a preocupação que tem os pesquisadores quando a abordagem tem um caráter qualitativo, muitos pensam que o objetivo seria a questão dos resultados e do produto, pelo contrário o segmento do processo seria a chave principal para os resultados, sem contar que existe dos dados indutivamente.

Os instrumentais escolhidos foram a observação não participante e a entrevista semiestrutura, que com base em Lüdke e André (1986). Quando se fala de entrevista a técnica mais adequada que se adapta aos estudos do ambiente educacional, seria uma que contém esque-

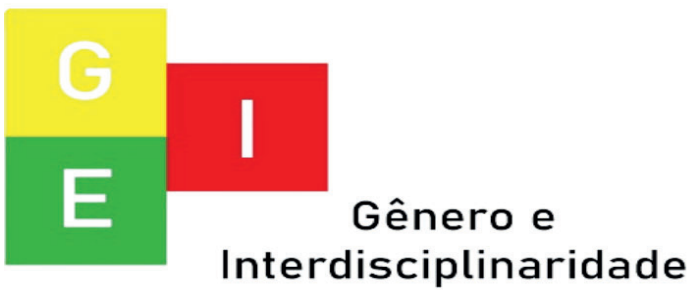


ma livre, pois esse instrumental é mais flexível no momento de entrevistar, sejam professores, alunos, pais, diretores, coordenadores, orientadores. Neste caso, a técnica de entrevista apresenta suas peculiaridades, pois os sujeitos da pesquisa ao serem entrevistados precisam de recursos que possa garantir uma abordagem positiva.

Essa entrevista foi realizada com 2 (dois) professores de ciências, que atendem a 3 escolas do campo, abordando os principais desafios e dificuldades enfrentados ao longo da trajetória enquanto professor dessa área.

Contou-se também com o auxílio da pesquisa bibliográfica e documental, em que foram analisados os planos de ensino, planos de aula e relatórios produzidos pelos profissionais da disciplina de ciências (biologia.fisica,química,matemática) das escolas do campo.

A análise de dados dessa pesquisa, deu-se a partir das análises de conteúdo com base em Bardin (2009), onde aponta que é característica desse método a expansão das aplicações da técnica a disciplinas, sendo assim bastante diversificadas pelo aparecimento de interrogações e novas respostas no plano metodológico.

Neste caso a pesquisa deu- se partir da seleção dos questionamentos da entrevista, em que participantes, descreveram com maior detalhe os procedimentos das práticas pedagógicas desenvolvidas durante suas aulas. Na sequência, serão identificados os temas geradores e os conceitos abordados, bem como, as principais potencialidades e limites percebidos acerca da proposta pedagógica para o ensino de Ciências no âmbito do ensino

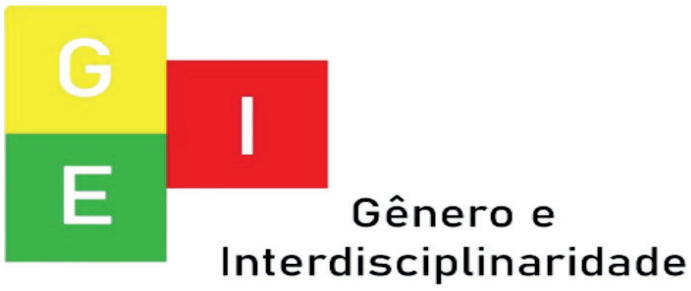


ISSN: 2675-7451

Vol. 02 - n 06 - ano 2021

Editora Acadêmica Periodicojs

e aprendizagem.

os alunos.

Pode-se perceber que

RESULTADOS E DISCUS- a Escola 1, passou por uma reSÕES

Caracterização das Escolas forma para melhor atender aos alunos e assim possibilitando conforto aos professores. A escola possui 07 salas de aulas, 01 No primeiro momento, sala de professores com banheifoi feito um levantamento das ro, uma área para construir uma escolas, dados importantes para a pesquisa. Inicialmente foi feito uma sondagem a respeito dessas escolas, analisando o perfil das comunidades, como dos alunos e professores, que ministram aulas nas escolas do campo, as dificuldades enfrentadas tanto pelas escolas como pelos os docentes, sendo que a maioria desses professores é da cidade de Timon. Procurou analisar tanto o perfil dos professores, como a infraestrutura dessas escolas, o que as mesmas oferecem de novidades para a clientela mais das comunidades que importante que são biblioteca, possui diretoria, cozinha e um depósito, uma área não coberta para pratica de esporte dos alunos, os alunos são transferidos de suas localidades através do ônibus escola, assim como os professores que utilizam o mesmo ônibus dos alunos, sem qualquer tipo de conforto.

A Escola 2, é uma escola de pequeno porte, possui 02(duas)salas de aulas,01(uma) diretoria,02 (dois)banheiros para os alunos,(o1(uma) cozinha,atendendo um público do povoado Onça, a comunidade possui 23 famílias, totalizando 43 alunos

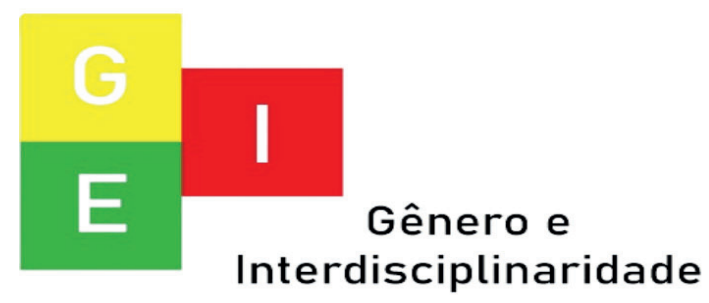


ISSN: 2675-7451

Vol. 02 - n 06 - ano 2021

Editora Acadêmica Periodicojs

matriculados na referida escola durante o turno da tarde, a noite recebe os jovens e adultos, proporcionado educação na modalidade EJA, I e II seguimento. A comunidade é participativa na escola, porém, foi relatado que a escola possui dois vereadores do município que auxiliam e são amigos da escola, são participantes e ativos na comunidade.

Esta escola tem duas salas amplas, dois banheiros, uma diretoria e uma sala para os professores, onde os mesmos não tem lugar para fazer suas reuniões, geralmente são realizadas no turno dos alunos para não prejudicar as aulas, assim garantindo o direito dos alunos terem os 200 dias letivos e 800 horas aulas. Já a Escola 3, é uma escola considerada polo, por atender uma maior número de alunos de comunidades vizinhas, pois não tem estrutura para atender os mesmos com qualidade, em termo de estrutura possui 05 salas de aulas, 01 diretoria, 01 cozinha e dois banheiros, sem área para práticas esportivas, ainda não esta climatizada,a reforma esta prevista para o corrente ano.

Figura 1: Escola 1

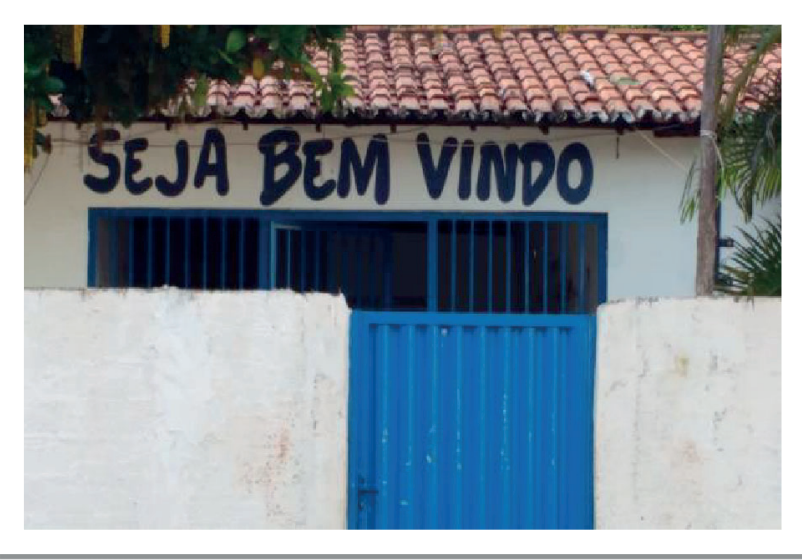

Fonte: Dados da autora, 2018
Figura 2: Escola

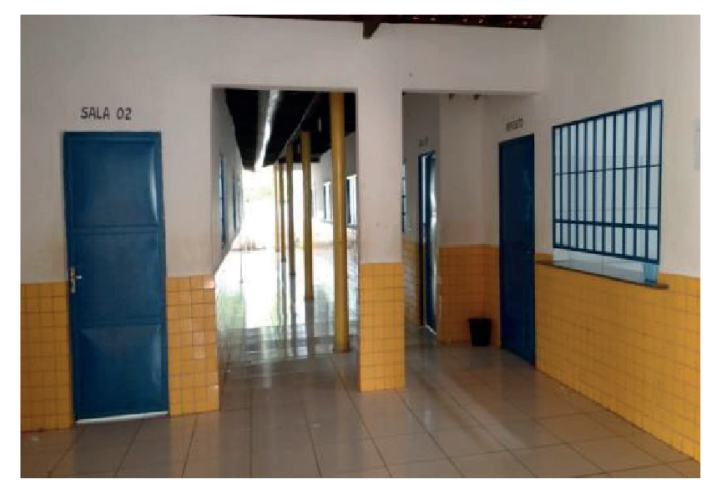

Fonte: Dados da autora, 2018

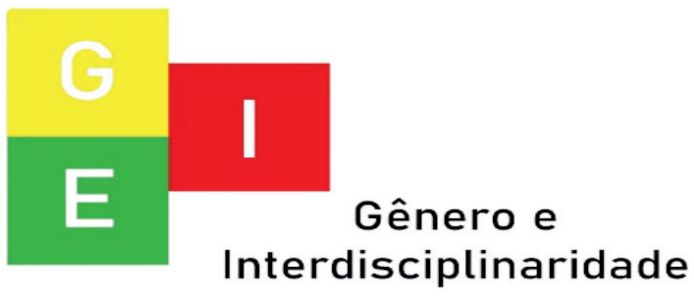


Figura 3: Escola 1

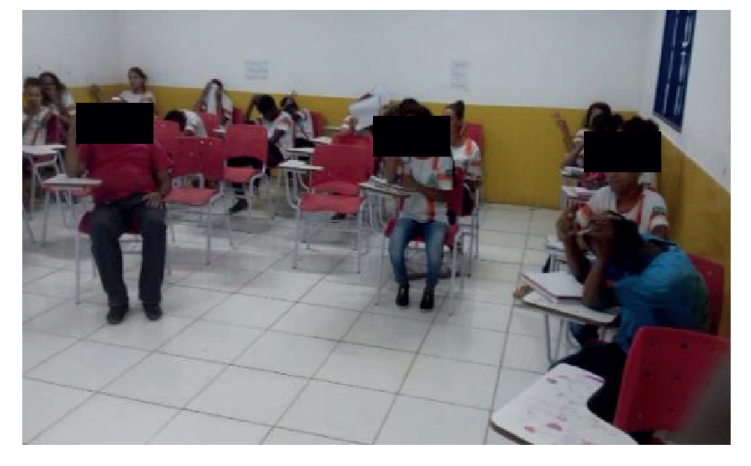

Fonte: Dados da autora, 2018
Figura 4: Escola 2

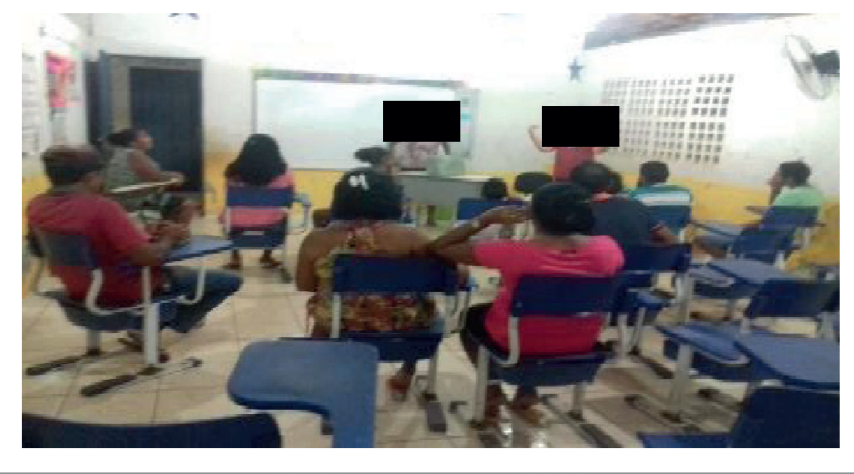

Fonte: Dados da autora, 2018

PERFIL E A T U A - das foram retiradas com a per-

\section{ÇÃO DOS DOCENTES}

No que se refere o perfil dos docentes pesquisados, pode-se observar diante do diagnóstico levantado, a caracterização dos professores que ministram aulas nessas escolas, além da sua atuação e metodologia de ensino, pois cada docente traz uma forma de lecionar sua disciplina, da forma que achar melhor a transmissão do conhecimento para os discentes, delineando a sua pedagógica.

As imagens supracitamissão dos docentes durante o período de observação da pesquisa, as quais validam as informações sobre as singularidades e subjetividade da construção da prática, a forma e estratégias de condução da aula, de cada professor.

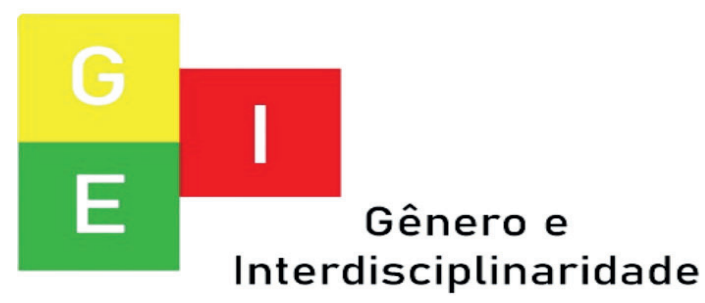


ISSN: $2675-7451$

Vol. 02 - n 06 - ano 2021

Editora Acadêmica Periodicojs

Tabela 2- Perfil dos docentes da área de Ciências Naturais

\begin{tabular}{l|l|l} 
& \multicolumn{1}{|c|}{ Professor A } & \multicolumn{1}{c}{ Professor B } \\
\hline Sexo & M & F \\
\hline Faixa etária & Mais de 55 anos & De 36 a 45 anos \\
\hline Escolaridade & Lic. Em química & Lic. Em física. Mestrando em matemática \\
\hline $\begin{array}{l}\text { Tempo de } \\
\text { serviço }\end{array}$ & De 10 a 15 anos & De 15 a 20 anos \\
\hline $\begin{array}{l}\text { Situação } \\
\text { profissional }\end{array}$ & Efetivo & Efetivo \\
\hline $\begin{array}{l}\text { Carga horária } \\
\text { de trabalho }\end{array}$ & 40 horas & Mais de 40 horas
\end{tabular}

Fonte: Dados da pesquisadora (2018).

$\mathrm{Na}$ tabela 2, pode-se dos pela Universidade Estadual perceber que os participantes da do Piauí (UESPI). Este aspecto pesquisa possuem formação em é relevante, os professores têm áreas afins as de Ciências da Na- conhecimento direcionado, satureza, os professores possuem beres específicos das disciplinas graduação, o professor A é for- ministradas, porém excede as mado em química, ministrando disciplinas para complementar a aula nas disciplinas de Ciências, carga horária, assim assumindo Artes, química, física, história, disciplinas que não são de seu e geografia. O professor $\mathrm{B}$, tem conhecimento específicos.

formação em Licenciatura em Matemática, ministra aula em Garcia et al. (2006), vem mostrar matemática e história.

Os professores particique em certos casos alunos tanto do ensino fundamental como pantes desta pesquisa, são formado ensino médio, continuam a ter

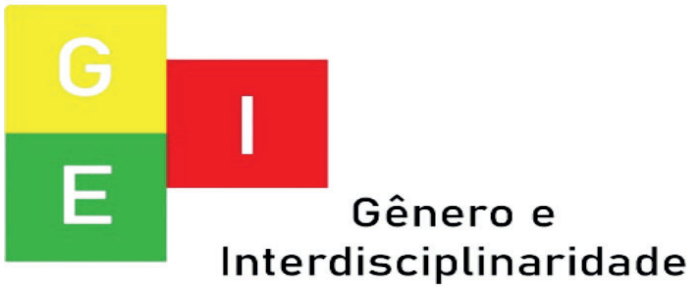


ISSN: 2675-7451

Vol. 02 - n 06 - ano 2021

Editora Acadêmica Periodicojs

aula com professores formados em outras áreas, sem as devidas credenciais para ministrar a disciplina de forma definitiva, mas apenas precárias e provisória.

Cada docente citado nesta pesquisa, trabalha em dias alternados nas referidas escolas, assim chamados de professores volantes, pois não ficam apenas em uma escola, mais complementam a sua carga horária em outras escolas. .

Este panorama, pode ser analisado a partir de dados da secretária municipal de educação do município, no que se tratam as escolas do campo. São aproximadamente 94 escolas do campo, onde atuam 324 professores, no ensino fundamental e médio. Os quais atendem a uma realidade de 6.184 alunos matriculados no município.

Diante dessa realidade, a rede apresenta uma parte de seus professores que atuam em disciplinas as quais não foram formados, isso é uma dificuldade, pois, de acordo com a lei de Diretrizes e Bases da Educação Nacional- LDB, de 1996, em seu artigo 36, inciso II, evidencia a necessidade de adoção de metodologias de ensino que estimulem a iniciativa dos estudantes. Porém, os docentes ao ministrar aulas de uma disciplina diferente daquela sua formação, o mesmo apresenta dificuldades para elaborar atividades que envolvam os discentes ou até mesmo para escolher o método mais eficiente na aplicação dos conteúdos específicos.

Quando se trata desvio de função, como é o caso que ocorre em várias escolas principalmente do campo, é um parecer que deve ser analisado. Há pessoas que são efetivos em uma determinada área, mas atua

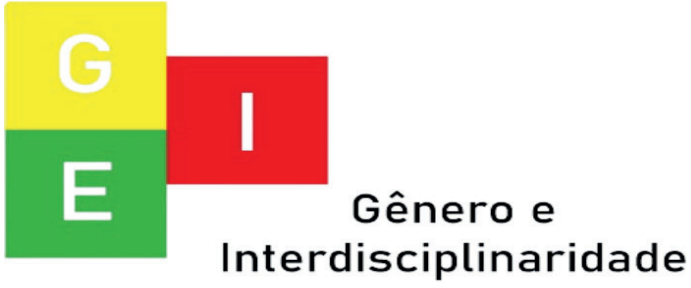


ISSN: 2675-7451

Vol. 02 - n 06 - ano 2021

Editora Acadêmica Periodicojs

em outra, como pode analisar no quadro 1 , onde fica claro que o profissional A, exerce a função de professor de química, mas é efetivo como secretário de escola. No caso específico dos servidores públicos, das mais diversas esferas, pode-se afirmar que um número muito grande de situações que caracterizam desvio de função existe dentro das esferas e estruturas administrativas (VICTORIO apud SILVEIRA, 2010, p.18-19).

Os pesquisados são efetivos da Prefeitura municipal de Timon, sendo que o Professor A, começou sua carreira como servidor como secretário escolar do município, em seguida, pediu mudança de função para docente, o qual foi concedido através de portaria.

No que se refere ao tempo de serviço, observa-se a variação de mais de 10 anos de traba- lho, e na escola que atualmente trabalha já está atuando há 10 anos, o professor A, e o professor B já está na mesma escola há 15 anos.

Seguindo a lógica do tempo de serviço e da trajetória profissional dos professores, $\mathrm{Hu}-$ berman (2000), destaca uma visão ampla no que diz respeito às preocupações que o professores, tem consigo principalmente no início da carreira, sendo uma delas o fato dos desencontros entre os ideais e a realidade que surge nesse trajeto. Com isso, há um sentimento de competência, onde os mesmos buscam conhecimento a partir de estudo nos objetivos de superar os desafios no início da carreira, para que ao chegar ao final da carreira docente possa traduzir um sentimento de conformismo de sua prática, além de uma serenidade profissional.

Os partícipes da pes-

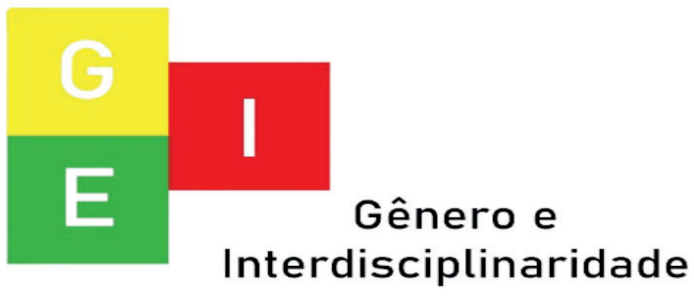


ISSN: 2675-7451

Vol. 02 - n 06 - ano 2021

Editora Acadêmica Periodicojs

quisa demonstram que já estão

na educação há muitos anos, isso

termina gerando uma indisposi-

ção e um cansaço mental, segun-

do suas colocações.

Ao serem questionados

sobre a opção de trabalharem nas

escolas do campo, os professores

alegam que já estão na área há alguns anos e escolheram ir para

a educação do campo devido à facilidade de se aposentar mais cedo. Além de encontrarem alguns "benefícios" em sua faixa etária. Pode-se observar este aspecto, através do relato:

"Eu prefiro vir para a Zona Rural devido,pois a clientela são bem melhor do que dazona urbana". (Professora A)

Este tipo de relato a uma relação ao compromisso e a qualidade da educação do campo, bem como a atuação, eficácia, rendimento e aprendizagem dos alunos.Pois o professor identifica um perfil de alunado diferente da zona urbana.

Partindo das ideias de Caldart (2002, p. 36), pode-se observar a importância do envolvimento dos docentes que atuam na educação do campo, onde ressalta que : "a construção de uma nova identidade de educador forjada nos movimentos por uma educação no campo e do campo. Formada/ formado "do" e "desde" o povo que vive no campo inserido como sujeito das políticas públicas e do projeto educativo em construção. (CALDART, 2002, p. 36)

Os docentes do município, são professores que já estão

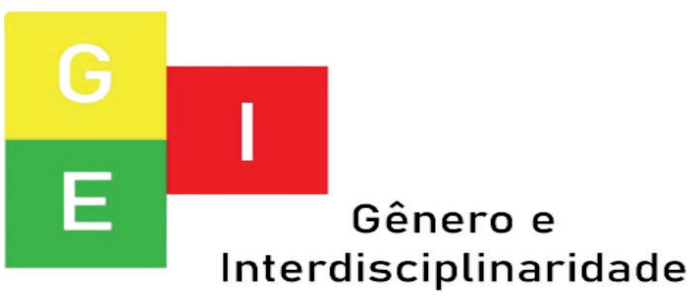


ISSN: 2675-7451

Vol. 02 - n 06 - ano 2021

Editora Acadêmica Periodicojs

exercendo a função há muito tempo, porém, nem todos tem a formação exigida para estar em sala de aula. Há professores efetivos e não concursados,. E desde então, os mesmos estão como efetivos no município, alguns concluíram graduação, especialização e até mesmo mestrado, mas a grande demanda de professores efetivos são os que não estão nesse quadro, e sim, os contratados.

Durante muito tempo, a educação no campo foi vista erroneamente, como uma forma de se aposentar mais cedo, ter gratificação, jornada de trabalho menor, redução de carga horária, apesar de todas as dificuldades. $\mathrm{Na}$ visão de alguns professores, ministrar aula na educação do campo tinha suas vantagens.

Nesse cenário, ancora o fato de muitos professores do campo costumarem fazer parte de um círculo vicioso e perverso, em que são vítimas de um siste-

ma educacional que desvaloriza

o seu trabalho, que coloca o campo como penalização e não como uma escolha. Esses professores acabam por realizar um trabalho desinteressado, desqualificado e que não leva em consideração o contexto em que estão inseridos e os sujeitos que o constituem (ARROYO;CALDART; MOLINA, 2004).

Essa visão vem sendo superada, devendo assim, resgatar a importância de uma educação de qualidade para os povos do campo. Primando pelo resgate os saberes campesinos e os saberes construídos ao longo dos anos na escola, por professores e alunos.

\section{A IMPORTÂNCIA DA FOR-} MAÇÃO PARA A PRÁTICA PEDAGÓGICA

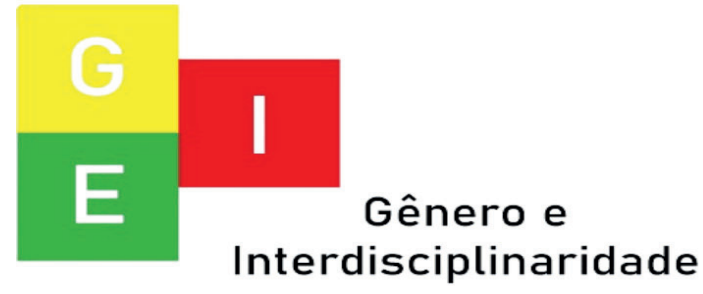


ISSN: 2675-7451

Vol. 02 - n 06 - ano 2021

Editora Acadêmica Periodicojs

A formação é de extre- ção continuada, a questão do ma importância para construção “continuum" fundamentado na da pratica pedagógica do professor que atua no campo. Para Nóvoa (1999), o mesmo faz uma declaração a respeito da impossibilidade de mudanças educativas, sem passar pela formação do professor. Essa citação nos faz lembrar que não basta somente falar, é preciso agir de forma a contribuir para a valorização dos ciclos de vida do profissional, onde valorize suas experiências enquanto docente, onde passara por toda fases, desde alunos até professor reformado. Contudo, é a partir de então que surge o que chamamos de mudanças educativas, há um determinado caminho a ser percorrido pelos professores, caso um degrau seja pulado futuramente farás diferença no contexto educacional.

Marin (1995) toca em algo interessante sobre a formaformação de professores, onde ele situa a educação permanente, formação continuada ou educação continuada, esses termos traz uma significância com relação o contexto educacional, no tocante a qualificação na busca do conhecimento.

Ao serem questionados sobre as formações do oferecidas pela SEMED do município de Timon, os professores investigados relataram que não são produtivas, pois não são direcionadas aos professores de área que atuam no Campo, pois a realidade é bem distinta da Zona Urbana. Os professores alegam que as capacitações oferecidas pela Secretaria de Educação, em não contribuem em sua formação, assim, tendo pouca relevância no desenvolvimento do processo ensino aprendizagem, pois não há recursos

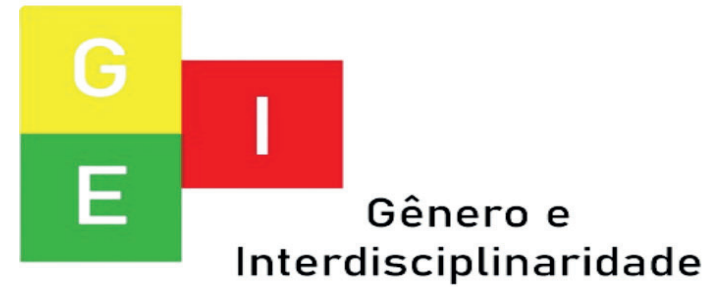


ISSN: 2675-7451

Vol. 02 - n 06 - ano 2021

Editora Acadêmica Periodicojs

didáticos que possam ajudá-los a desenvolver uma metodologia de caráter significativo aos alunos.

De acordo com os relatos, os professores preferem não participar das capacitações, pois não são voltadas a realidade da educação do campo, o que os desmotiva a participar, sentem-se excluídos durante a formação, pois não atende as necessidades que o campo exige.

Arce (2011), Martins (2010), denunciam que as políticas de formação de professores têm sido guiadas sob égide ideologia neoliberais e pós-moderna, vislumbrando um projeto de desenvolvimento para atender e solucionar os problemas do mercado capitalista, buscando conhecimento e informações necessárias para a ocupação dos postos de trabalho. Isto mostra que a formação de professores tem sido orientada por uma vi- são tecnicista e produtiva onde conhecimentos precisam ser relevantes para a vida pratica, úteis para melhorar a competitividade no mercado de trabalho e desprovido de conteúdos críticos. Nas palavras de Sousa \&Fontana (2013, p.17).

(...) as políticas para a formação dos professores buscam conciliar perspectivas pedagógicas hegemônicas com os interesses economicistas da classe dirigente dos pais. Os professores aprenderem nos cursos de formação e reproduzirem os princípios, objetivos, conteúdos e métodos da "educação interessada, ou ideológica", desarticulados as reais condições da escola pública e necessidades emancipatórias dos seus alunos, colaborando para a manutenção do sistema de

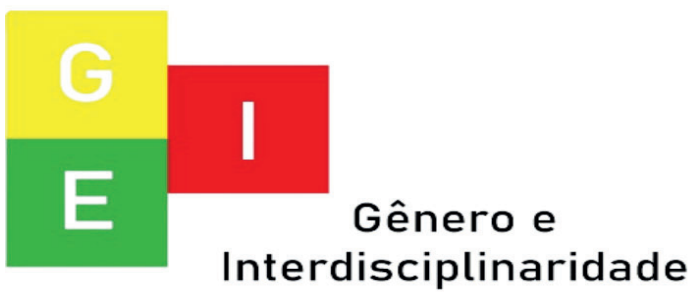


ISSN: 2675-7451

Vol. 02 - n 06 - ano 2021

Editora Acadêmica Periodicojs

desigualdade social nos últimos três (3) anos, resga(SOUSA \&FONTANA, 2013, p.17). tamos a fala dos partícipes que declaram:

No que se refere à participação e curso de capacitação

“Não. Não demonstra interesse. Não gosto de gastar dinheiro com isso e a SEMED, não proporciona curso interessante" (Professor A).

"Sim. Formação em curso sobre étnico racial, diversidade, grupo de estudo para omestrado na Bahia-BA" (Professor B).

De acordo com os dados jetivo de atender as demandas da obtidos, através do diagnóstico realidade do campo. Além disso, dos professores podemos obser- formação sobre ciências e tecnovar nessa pesquisa, certas limi- logias voltadas para o campo, no tações entre os profissionais da qual totalizando uma carga horáeducação da área de ciências naria de 20 e $40 \mathrm{~h}$.

turais. O professor A, não partiOs professores particicipou de nenhuma formação, nos pam de formações continuada últimos anos, enquanto o professor B, participou de formações com o supervisor (a) do pólo, o mesmo tenta suprir necessidades em outras áreas de interesse pessoal, como palestra voltada a área de metodologias diferenciadas que deixam os professores instigados durante o ano letivo. A cada bimestre, o supervisor (a) para classe multisseriada, no obfaz uma formação ao qual dar su-

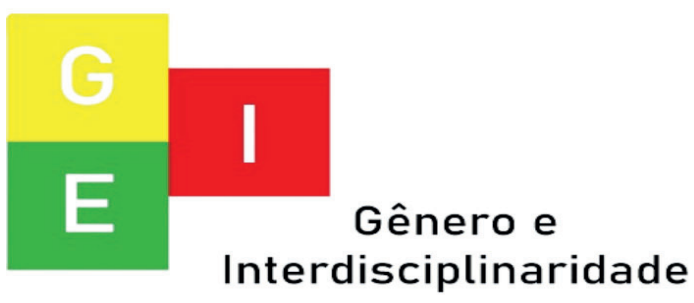


ISSN: 2675-7451

Vol. 02 - n 06 - ano 2021

Editora Acadêmica Periodicojs

porte pedagógico com informações, e com temas direcionados aos professores da educação do campo, de acordo com cada realidade e especificidade de cada comunidade como um todo.

Diante dos resultados colhidos, começa a perceber a questão da falta de outras formações continuadas, para que possa aprimorar os conhecimentos na área, pois a cada dia os professores necessita fazer cursos, no objetivo de enriquecer seu currículo profissional.

Quanto a contribuição dos cursos para prática pedagógica dos professores, observou-se que o professor $\mathrm{A}$, não demonstra interesse em fazer cursos de aperfeiçoamento, informa que a própria Secretaria de Educação não traz cursos significante para sua área de conhecimento, em como não demonstra interesse em se capacitar para obter uma base teórica que possa lhe auxiliar na metodologia de ensino em sala de aula. O docente encontra-se atuante na profissão cerca de 25 anos de trabalho, cujo deixa claro que não tem interesse em se aperfeiçoar, pois o mesmo já está à espera de sua aposentadoria.

Sobre a temática, a professora B, demonstra interesse em se qualificar, porém não acha atrativas as formações da Secretaria de Educação, pois não acham que não seja voltada diretamente a área afim, cujo não vai de encontro a realidade do processo de aprendizagem do campo. Acredita que a formação melhora a sua metodologia em sala de aula, no processo avaliativo e até mesmo na execução do planejamento. Sente falta da parceria da SEMED, acatar uma metodologia a ser desenvolvida de forma significava para com os alunos, já que não possui recursos didáticos

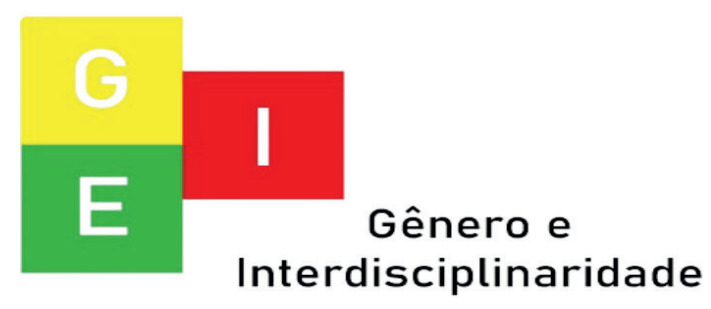


ISSN: 2675-7451

Vol. 02 - n 06 - ano 2021

Editora Acadêmica Periodicojs

propícios, assim impossibilitando aos alunos a um crescimento no processo ensino aprendizagem.

Ao tratar sobre as formações realizadas pelos professores, foram destacados alguns pontos. O primeiro a ser observado estava relacionado à melhoria do processo de ensino aprendizagem, o professor A afirma acredita não haver contribuição neste processo, enquanto o professor $\mathrm{B}$, acredita que só contribui em parte.

Nota-se ainda, que todas as pessoas envolvidas na pesquisa possuem experiência em sala de aula, isso é importante, influencia na prática pedagógica, contribuindo de certa maneira na relevância dos resultados obtidos, através desses saberes advindo da experiência em sala de aula, o profissional vai se habituando e tomando conhecimento na maneira correta de ensinar aos seus alunos. Essas idéias corroboaram com a visão de Tardif (2002, p.36), pois afirma que os saberes dos professores estabelecem um "saber plural, formado pelo amálgama, mais ou menos coerente, de saberes oriundos da formação profissional e de saberes disciplinares, curriculares e experiências".

O movimento da Educação do Campo busca não alimentar esse antagonismo, mas a reflexão da situação em que se encontra a área rural, e através dessa reflexão, o diálogo entre culturas, entre realidades que se complementam na interação entre campo e cidade como camponês importante para o desenvolvimento da nação brasileira.

A mudança de paradigma de educação rural para a educação do campo não se traduz de forma tão simples, uma vez que necessita de transformações es-

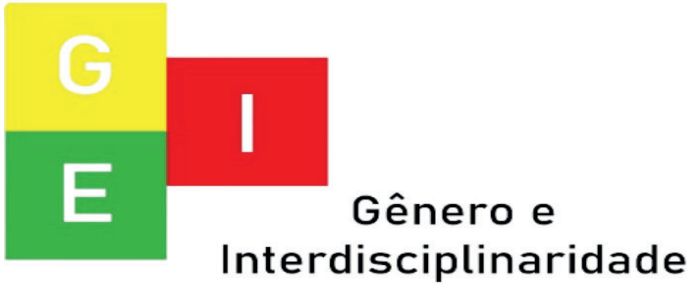


ISSN: 2675-7451

Vol. 02 - n 06 - ano 2021

Editora Acadêmica Periodicojs

truturais. E um pensar sobre a educação do campo para o qual nem os sistemas de ensino, nem os currículos, nem as escolas e nem os docentes estão preparados. É um novo pensar sobre a educação do campo para o qual nem os sistemas de ensino, nem os currículos, nem as escolas e nem os docentes estão preparados. E suscitados um novo professor, ou melhor, educador, nas palavras de Caldart (2004) e de Arroyo (2004, 2011), considerando um conceito mais ampliado do termo educador (a), como aquele ou aquela que faça e pense a educação humana escola, na família, na comunidade, no movimento social, na educação de crianças, jovens e idosos.

A necessidade de formar professores para o campo tornou-se um grande desafio, pois conforme vimos às formações de professores inicial, conti- nuadas ou em serviços não estão preparadas para o atendimento ás especificidades e a diversidade do campo: fazer a integração entre os conteúdos escolares e o conteúdo advindo da vida, do cotidiano, da história, memórias e cultura dos educando, da comunidade, do local, do campo.

\section{CONSIDERAÇÕES FINAIS}

O presente trabalho buscou investigar a relevância da formação continuada dos professores pesquisados. Pois, acredita-se que a temática, contribui para provocar mudanças na organização pedagógicas da escola e comunidade.

De acordo com o exposto apresentado, pode-se analisar que a pesquisa trouxe uma abrangência no âmbito do conhecimento da realidade do campo, como também os desafios e dificulda-

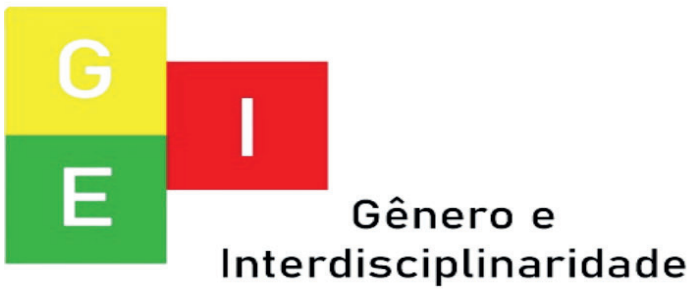


ISSN: 2675-7451

Vol. 02 - n 06 - ano 2021

Editora Acadêmica Periodicojs

des vivenciadas pelos docentes que fazem parte desse processo.

Observa-se que o campo ainda necessita de pessoas com uma visão consciente e transformadora com relação a realidade campesina, pois há muito que melhorar, principalmente na questão da educação, a qual é desafiante.

Diante dessas delimitações, convém salientar que existe uma necessidade em trazer um ensino diferenciado para essas escolas, mostrando para os alunos que mesmo com os problemas enfrentadas pode se fazer diferença na educação, suscitando que todos podem ser incluídos onde a educação é um direito de todos.

O caminho da pesquisa é um legado cheio de desafios, limitações para com o contexto analisado da realidade, onde se busca abranger os resultados propostos em questão diante da proposta; reflexão, análise, conclusões são pontos de vista formados a partir da visão de mundo e da escolha dos parâmetros científicos definidos para dar sustentação ás analises.

Acredita-se que os objetivos propostos inicialmente pela pesquisa, tenham sidos contemplados, pois dos achados durante o processo da investigação, observou- se que os professores possuem formação para atuarem do $6^{\circ}$ ao $9^{\circ}$ ano, porém não ministram aulas somente nas suas disciplinas de sua formação, ambos trabalham com diversas disciplinas, com o intuito de completar a carga horária proposta pela secretaria municipal, não sendo exigida a formação específica. Identificou-se o perfil dos docentes que atuam do $6^{\circ}$ ao $9^{\circ}$ ano no ensino fundamental na escola do campo, no município de Timon-

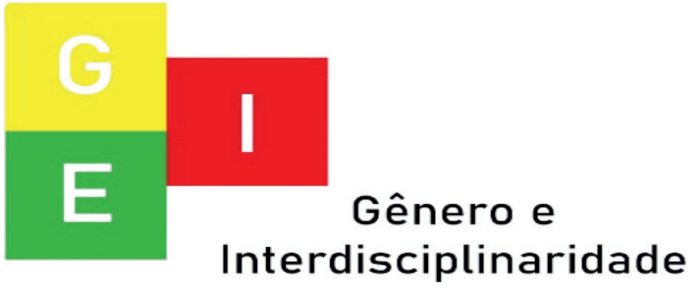


ISSN: 2675-7451

Vol. 02 - n 06 - ano 2021

Editora Acadêmica Periodicojs

-MA, são formados na área e está há mais de 15 anos nas mesmas escolas, ministrando disciplinas diferenciadas da formada inicial.

Quanto as formações continuadas, observou-se que houveram poucas contribuições para o desenvolvimento da prática pedagógica dos professores que atuam nas escolas do campo. Diante dos relatos dos professores, as formações realizadas pela SEMED, não contribui de forma significativa para os mesmos, pois não são voltadas a realidade do campo e a cada formação, sentem-se excluídos, pois tudo é voltado para a zona urbana. Além disso, as temáticas também não são atrativas. Quando são convidados a participar das formações, preferem ir ministra as aulas. Existem formações na própria escola, realizado pela supervisão escolar, com o intuito de procura atender as necessida- des dos mesmos. Os temas são variados geralmente traz a comunidade para dentro da escola, são momentos de troca de experiências e exposição de dificuldades e angustias, trazendo resultados significativos para a escola.

Há necessidade de uma pedagogia emancipatória que permita redefinir a concepção de ensino - aprendizagem. É preciso aprofundar com todos os profissionais da educação as discussões em torno da organização do trabalho pedagógico, entendendo suas relações com o contexto mais amplo e, para isto requer, sem dúvida, repensar a formação docente, tanto dos professores que atuam na educação do campo.

Conclui-se que se faz necessário uma maior discussão sobre as reais necessidades formativas dos docentes da área de Ciências da Natureza da Educa-

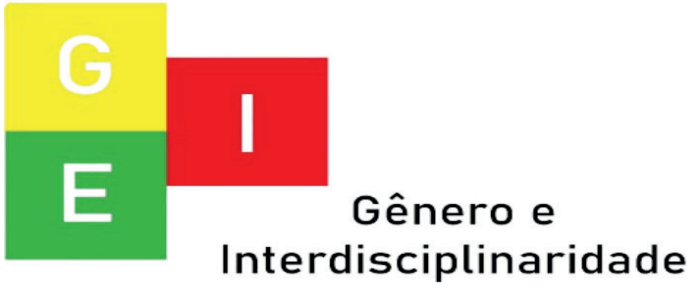


ISSN: 2675-7451

Vol. 02 - n 06 - ano 2021

Editora Acadêmica Periodicojs

ção do Campo, corroborando a importância do seu papel como mediador no desenvolvimento do processo de ensino aprendizagem dos discentes, cujo são os protagonistas de toda ação educativa. Devendo prevalecer a troca de saberes entre a escola e comunidade e as especificidades da educação do campo.

\section{REFERÊNCIAS}

ARRUDA, S. M.; LABURÚ, C. E. Considerações sobre a função do experimento no ensino de ciências. In: NARDI, R. (Org.). Questões atuais no ensino de ciências. São Paulo: Escrituras Editora, 2001. p. 53-60.

BRASIL. Lei 5.692, de 11 de agosto de 1971. Fixa diretrizes e bases para o ensino de $1^{\circ}$ e $2^{\circ}$ graus, e dá outras providências.
Diário Oficial da União, Brasília, 12 ago. 1971. Disponível em: $<$ http://www010.dataprev.gov. br/sislex/paginas/42/1971/5692. htm>. Acesso em: 04 de janeiro de 2019.

BRASIL, Ministério da Educação e Cultura. PCN - Parâmetros Curriculares Nacionais: Terceiro e Quarto Ciclos do Ensino Fundamental - Ciências Naturais. Brasília, 1998.

BARDIN, L. Análise de Conteúdo. Lisboa, Portugal; Edições 70, LDA, 2009. CAVACO, M.H. Ofício do professor: o tempo e as mudanças. In: NÓVOA, A. (Org.). Profissão professor. 2. ed. Porto: Porto, 1999. p.155-91.

CALDART, R. S. Educação do campo: notas para uma análise de percurso. Trabalho, Educação e Saúde, Rio de Janeiro, v. 7 n. 1,

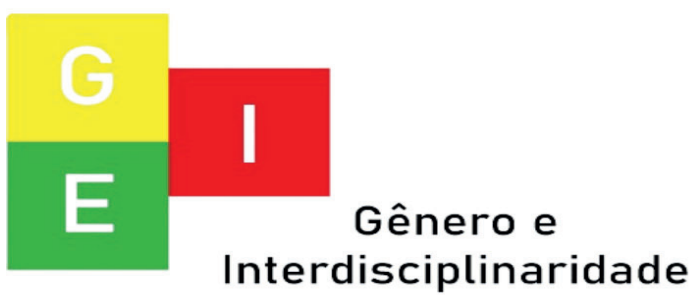


ISSN: 2675-7451

Vol. 02 - n 06 - ano 2021

Editora Acadêmica Periodicojs

p. 35-64, mar./jun.2002.

CACHAPUTZ, Antonio et al. A necessária renovação do ensino de ciências. São Paulo: Cortez, 1989.

CLEONICE， P., HERBERT, G.M., PATRICIA, M. D.C., SONIA, R.M.S. Didáticas específicas e formação continuada de professores: $\mathrm{O}$ caso do mestrado em ensino das ciências. Cambridge, University of Cambridge, P. 18 D, 10 abr. 2011.

FREIRE-MAIA，N. A ciência por dentro. 5. ed. Petrópolis: Vozes, 1987. 262 p.

FRANCO, M.A.R. S. Entre a lógica da formação e a lógica das práticas: a mediação dos saberes pedagógico. In: Reunião anual da anped, 29., 2006, Caxambu. Anais... Caxambu: Anped, 2006 a. Sessão Especial. 1 CD-ROM.

FERNANDES, J.A.B. Você vê essa adaptação? A aula de campo em ciências entre o retórico e o empírico. São Paulo, 2007. 326p. Tese (Doutorado em Educação) Faculdade de Educação, Universidade de São Paulo, São Paulo, 2006. INSTITUTO BRASILEIRO DE GEOGRAFIA E ESTATÍSTICA - IBGE. Censo demográfico 2010: Tabela com dados sobre a população urbana. IBGE, 2010. Disponível em: $<$ https:// ww2.ibge.gov.br/home/estatistica/populacao/censo2010/sinopse/ sinopse_tab_ brasil_zip.shtm> Acesso em: 20 de junho de 2018.

GARCIA, P.S. Two case studies about Science teachers initial preparation in Brazil. In: XII Symposium of the International Organization for Science and Tecnology Education. IOSTE

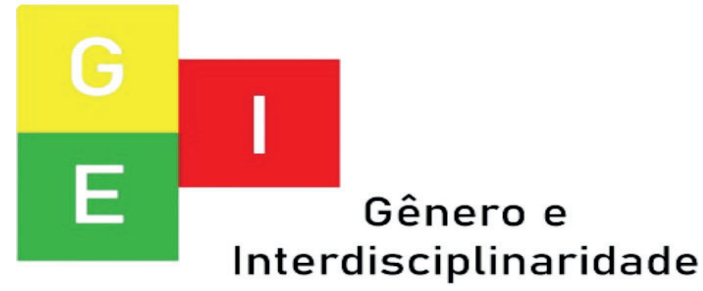


Vol. 02 - n 06 - ano 2021

Editora Acadêmica Periodicojs

proceedings, University of Malaysia, 2006. p. 31-36.

MOLINA, M. C. Desafios teóricos e práticos na execução das

HUBERMAN, M. O ciclo de políticas de Educação do Campo. vida profissional dos professores. In: MUNARIM, A. BELTRAIn: NÓVOA, A. (Org.). Vidas de ME, S. ; CONDE, S. F.; PEIXER, professores. 2.ed.Porto: Porto, 2000. p.31-61.

I. (Org.). Educação do Campo, Reflexões e perspectivas. 1. ed. Florianópolis: Insular, 2004, v. 1, LÜDKE, M.; ANDRÉ, M.E.D.A. p. $103-122$

Pesquisa em educação: abordagens qualitativas. São Paulo: EPU, 1986.

MOURA, Terciana V., SANTOS, Fábio J. S. dos. A pedagogia das classes multisseriadas: um olhar MARIN, A.J. Educação continuada: introdução a uma análise de termos e concepções. São Paulo: Papirus, 1995.(Cadernos CEDES 36: Educação Continuada, p.1320). sobre a prática pedagógica dos/ as professores/as da roça do município de Amargosa-BA. In: Elizeu Clementino de Souza. (Org.). Educação e Ruralidades: memórias e narrativas (auto) biográfica. Educação e Ruralidades: memóMILLAR, R. Towards a science rias e narrativas (auto) biográfica. curriculum for public understanding. School Science Review, Salvador: EDUFBA, 2012, v., p. 269-297.

London, v. 77, n. 280, p. 7-18, 1996.

OLIVEIRA, Cristiano Lessa de.

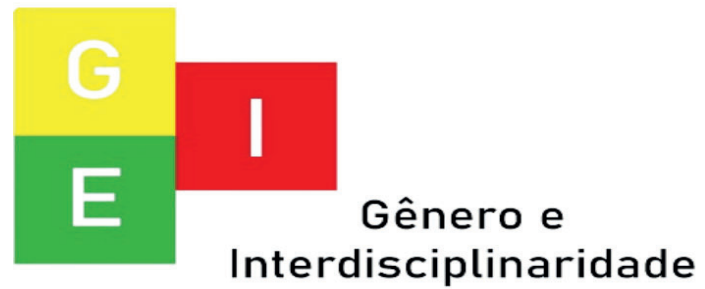


Um apanhado teórico-conceitual sobre a pesquisa qualitativa: tipos, técnicas e características. Revista travessia, Alagoas, p. 0314, 1982.

PARANÁ, Secretaria de Estado da Educação. Diretrizes Curriculares da Educação do Campo no Paraná. Curitiba: SEED, 2006.

PIMENTA, S. G. (org.). Didática e formação de professores: percursos e perspectivas no Brasil e em Portugal. São Paulo: Cortez, 2000.

STINNER, A.; WILLIAMS, H. History and philosophy of science in the science curriculum. In:FRASER, B.; TOBIN, K. (Ed.). International Handbook of Science Education. Dordrecht: Kluwer Academic Publishing, (part two), 1998. p. 1027-1045.

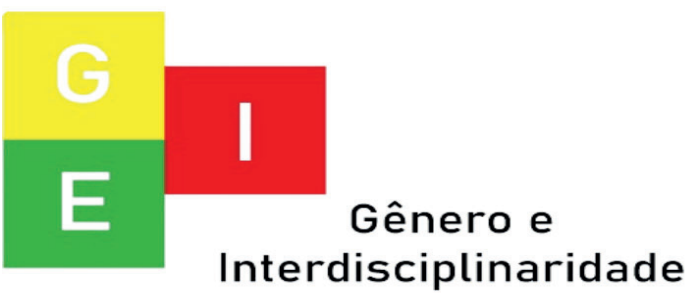

SCHNETZLER, Roseli Pacheco.

Prática de ensino nas ciências na-

turais: desafios atuais e

contribuições de pesquisa. In: ROSA, Dalva E. Gonçalves; SOUZA, Vanilton Camilo de (Orgs.). Didática e práticas de ensino: interfaces com diferentes saberes e lugares formativos. Rio de Janeiro: DP\&A, 2002, p. 205222.

SOBRINHO, R.S. A importância do ensino da biologia para o cotidiano. Programa especial de formação pedagógica de docentes na área de licenciatura em biologia. Fortaleza, CE. 2009. Disponível em: http://www.nead. fgf.edu.br/novo/material/monografias_biologia/RAIMUNDO_ DE_SO USA_SOBRINHO.pdf. Acesso em 10 de março de 2014.

SILVEIRA, L.R. Desvio de função no serviço publico: seu Con- 
ISSN: 2675-7451

Vol. 02 - n 06 - ano 2021

Editora Acadêmica Periodicojs

trole e as Decisões dos Tribunais,

2010. Disponível em:< http://

hdl.handler.net/123456789/606.>

Acesso em: 02 de fevereiro de

2019.

TRIVIÑOS, Augusto Nibaldo

Silva. Introdução à pesquisa em

ciências sociais: a pesquisa qua-

litativa em educação. São Paulo:

Atlas, 1987.

TARDIF, M. docentes e formação profissional. Petrópolis: Vozes, 2002.

TARDIF, M. Saberes docentes e formação profissional. Petrópolis: Vozes, 2005.

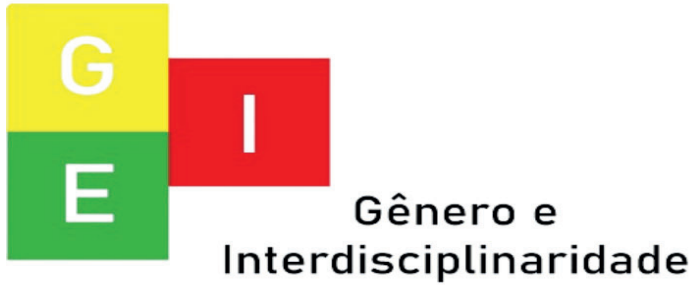

